\title{
Effect of kafirin protein coating on sensory quality and shelf-life of 'Packham's Triumph' pears during ripening
}

\author{
Sonya Buchner ${ }^{\mathrm{a}, \mathrm{b}^{\star *}}$, Marise Kinnear ${ }^{\mathrm{a}}$, lan J. Crouch ${ }^{\mathrm{c}}$, Janet Taylor ${ }^{\mathrm{a}}$, \\ Amanda Minnaar ${ }^{\mathrm{a}}$ * \\ ${ }^{a}$ Department of Food Science, University of Pretoria, Pretoria, $0002^{\mathrm{b}}$ Previously from CSIR, \\ Biosciences, P.O. Box 395, Pretoria, 0001, South Africa \\ ${ }^{c}$ Experico, (Fruit Technology Solutions), P.O. Box 7441, Stellenbosch, 7599, South Africa \\ * Corresponding author: Tel: +27 12420 3239; fax: +27 12420 2839. E-mail address: \\ amanda.minnaar@up.ac.za \\ ** Currently employed by Mars South Africa, P.O. Box 9111699, Rosslyn, Pretoria, 0200, South \\ Africa.
}

Running title: Post-harvest quality and shelf-life of kafirin-coated 'Packham's Triumph' pears 


\section{Abstract}

BACKGROUND: Pears are exported in large quantities from South Africa resulting in large revenues. Minimisation of quality losses once the fruit has reached the export destination is as important as following strict export and distribution protocols. Kafirin can form edible films. An edible coating, made from a $2 \%(\mathrm{w} / \mathrm{w})$ kafirin coating solution was applied as a post-harvest treatment to retard quality deterioration of 'Packham's Triumph' pears during storage at the typical ripening temperature $\left(20^{\circ} \mathrm{C}\right)$. The changes in physico-chemical and sensory quality were studied over a period of 24 days.

RESULTS: The kafirin coating was unable to retard the onset of ripening but decreased the respiration rate and retarded the progression of senescence. However, moisture loss was exacerbated in the kafirin-coated fruit during ripening at $20^{\circ} \mathrm{C}$ especially towards the end of the shelf-life.

CONCLUSION: The coating extended the eat-ripe quality of the pears between one and two weeks. However, appearance of the fruit was unacceptable after 14 days of storage in terms of wrinkled skin. Further work is needed to improve the water barrier properties of the kafirin coating by incorporating a wax or triglyceride into the coating formulation or more simply by applying a kafirin coating to waxed fruit.

Keywords: pear; protein coating; kafirin; ripening; senescence; physicochemical and sensory properties 


\section{INTRODUCTION}

Pears are climacteric fruit that are picked physiologically mature but unripe. They are stored under conditions that retard ripening until the retail destination is reached. They are then usually ripened at $20^{\circ} \mathrm{C}$ for 7 days to attain the eatripe stage. The variety "Packham's Triumph" is exported in large quantities from South Africa, resulting in large revenues for the South African fruit industry. The expected export estimates for 2010 is 6.1 million cartons (Lindhout, G http://www.freshplaza.com). Although strict protocols for pear export and distribution are in place (Anon - htpp://www.ppecb.com) ripening will commence once the cold chain is broken, particularly in markets and retail outlets that do not keep the fruit refrigerated. Undersirable ripening during storage and marketing may lead to losses in fruit quality and saleability and subsequently result in loss of revenue.

Edible coatings for pome fruit have long been investigated to extend fruit quality and shelf-life ${ }^{1,2}$. To retard ripening, the edible coating acts as a gas barrier through modification of the fruit's internal atmosphere by increasing $\mathrm{CO}_{2}$ and decreasing $\mathrm{O}_{2}$ concentrations, typical of modified atmosphere packaging $(M A P)^{3}$. Carnauba-waxes have been found to delay ripening in coated 'Packhams' Triumph' pears by blocking the pores ${ }^{4,5}$. However, the waxy taste of the peel was unacceptable to consumers. An edible coating that does not impart a waxy taste would be advantageous ${ }^{3}$.

Zein, the maize prolamin protein, has been shown to be an effective gas and moisture barrier when used to coat tomatoes ${ }^{6}$ and apples ${ }^{7}$. Kafirin, the sorghum prolamin protein is similar to zein in solubility, structure ${ }^{8}$ and amino acid composition ${ }^{9}$. Further, kafirin is more hydrophobic ${ }^{10}$ than zein and is non- 
allergenic $^{11}$. Theoretically, kafirin should be a better moisture barrier than zein and should provide the necessary gas barrier properties exhibited by zein. Free-standing kafirin films with similar functional properties to those of zein films have been made ${ }^{12,13,14,15}$. Consequently, it may be possible to maintain the quality and thus extend the shelf-life of 'Packham's Triumph' pears by using an edible kafirin coating to provide a barrier against moisture loss and gas exchange.

In this study a comparison was made between kafirin coated and uncoated 'Packham's Triumph' pears. The effect of the coating on the physiological behaviour and shelf-life of the pears was investigated.

\section{MATERIALS AND METHODS}

\section{Source of fruit}

Physiologically mature, unripe 'Packham's Triumph' (70 pears, average weight $178 \mathrm{~g}$, per $12.5 \mathrm{~kg}$ box; average pear surface $0.0135 \mathrm{~m}^{2}$ ) (Tru Cape in Elgin, South Africa) were used for preliminary coating and storage trials. 'Packham's Triumph' pears of similar size and maturity obtained from Colours Fruit in Paarl, South Africa was used for shelf-life trials.

Kafirin coated and uncoated 'Packham's Triumph' pears were stored for one week under regular atmosphere $(\mathrm{RA})$ conditions at $-0.5^{\circ} \mathrm{C}$ and then exposed to ambient (typical ripening) conditions $\left(20^{\circ} \mathrm{C}, 35-45 \% \mathrm{RH}\right)$. 


\section{Coating of pears}

Sorghum kafirin, protein content $836 \mathrm{~g} \mathrm{~kg}^{-1}$ (dry basis, $\mathrm{N} \times 6.25$ ) was extracted from milled, decorticated, non-tannin, red sorghum using the method of Emmambux and Taylor $(2003)^{16}$ with the following modifications. Protein was recovered by centrifuging through a basket centrifuge lined with a $5 \mu \mathrm{m}$ centrifuge cloth and air dried for $24 \mathrm{~h}$ under ambient conditions $\left(20-23^{\circ} \mathrm{C}\right)$ before defatting with $\mathrm{n}$-hexane for $3 \mathrm{~h}$. The dry, defatted protein powder was ball-milled for $16 \mathrm{~h}$. Coating solutions were prepared by dissolving kafirin in $70 \%(\mathrm{v} / \mathrm{v})$ aqueous ethanol containing plasticisers, 1,2-propanediol $\left(7.2 \mathrm{~g} \mathrm{~kg}^{-1}\right)$ (code 123638, Sigma Aldrich Chemicals, Johannesburg, South Africa) and glucono-delta-lactone $\left(3.6 \mathrm{~g} \mathrm{~kg}^{-1}\right)(\mathrm{CC}$ Immelman, Southdale Johannesburg, South Africa) at $70{ }^{\circ} \mathrm{C}$ with vigorous stirring. Ethanol $(98 \%, v / v)$ was added to replace the solvent lost during evaporation and the coating solution was then cooled to 20 to $25^{\circ} \mathrm{C}$.

Prior to coating pears were equilibrated to $20^{\circ} \mathrm{C}$. Pears were dipped in kafirin coating solution for five seconds and hung by the stem to dry for $4 \mathrm{~h}$ at $20^{\circ} \mathrm{C}$. A control of pears dipped in $70 \%(\mathrm{v} / \mathrm{v})$ ethanol was not included in this study. Although ethanol treatment has been shown to inhibit ripening in some fruits such as tomatoes ${ }^{18,19}$ and prolonged the shelf-life of broccoli florets ${ }^{20,21}$ showed that ethanol vapour failed to inhibit ripening of pears. After treatment, coated and uncoated pears were refrigerated at $0 \pm 1^{\circ} \mathrm{C}$ for seven days prior to commencement of the shelf-life study. 


\section{Experimental design}

For the shelf-life study 6 randomly selected groups of 36 treated pears and the same number of groups of untreated pears were used. Each group of 36 pears was placed as a single layer at the bottom of an open plastic container. Coated and uncoated pears were kept separately. Six pears within each group were used for respiration and moisture loss analyses. They were stored in an open glass jar within each container. The remainder of the pears were used for the analysis of fruit quality during storage. Storage was at $20^{\circ} \mathrm{C}$ and ambient $\mathrm{RH}$ (35- 45\%) for 24 days. Additional coated and uncoated pears to be used for descriptive sensory evaluation were stored under the same conditions.

Respiration rate and moisture loss was measured on the selected group of six pears from each of the six containers per treatment on days $0,3,4,5,6$, $7,9,10,11,14,17,21$ and 24 . The quality attributes, colour, firmness, soluble solids content and titratable acidity was measured on six pears (one from each container) on days $0,3,7,10,14,17,21$ and 24 .

\section{Respiration rate and moisture loss}

Respiration rate (mg $\mathrm{CO}_{2} \mathrm{~kg}^{-1} \mathrm{~h}^{-1}$ ) was measured using an infra red gas analyser (IRGA) (LI-COR gas analyser, model LI-6262, CS Africa, Somerset West, South Africa) on 6 groups of six pears per treatment, over a period of 10 min at $20^{\circ} \mathrm{C}$, in a closed system. Nitrogen gas $(99.9 \%$ pure) was used as a reference gas. The same group of six pears were used at each time interval. These pears were also used for moisture loss determinations. Mass difference was used as an indication of moisture loss and was calculated by weight 
difference of the fruit mass on day zero, and expressed as $\mathrm{g} \mathrm{kg}^{-1}$ moisture loss (on fresh weight basis).

\section{Quality attributes}

At each time interval, six pears per treatment (one pear from each storage container) were used for analysis of colour, flesh firmness, titratable acidity and total soluble solids. Colour was measured in triplicate on the cheeks of the pears using a ColourQuest Hunter colorimeter (HunterLab, Hunter Associates Laboratories Inc., Reston, Va., U.S.A.). The $a^{*}$ measures redness when positive and greenness when negative; $b^{*}$ measures yellowness when positive and blueness when negative ${ }^{22}$.

Flesh firmness was measured using a Stable Micro Systems Texture Analyser (Model TA-XT2i, Wirsam Scientific Ltd., Johannesburg, South Africa) using a $2 \mathrm{~mm}$ stainless steel probe, cross-head speed $5 \mathrm{~mm} / \mathrm{s}$, penetration distance $10 \mathrm{~mm}$ (Stable Micro Systems Application sheet Pear 1/P2, 2000). Pears were cut in half longitudinally. A strip of peel (10 mm wide, $30 \mathrm{~mm}$ long) was removed from the pear cheek of each half fruit, along the equatorial plane and three readings taken $10 \mathrm{~mm}$ apart along the skinned section. The firmness of the flesh directly below the peel was designated external flesh firmness and at $10 \mathrm{~mm}$ deep internal flesh firmness.

Titratable acidity (TA) was determined on $6 \mathrm{~g}$ pear juice obtained from the filtrate of a single homogenised pear. The pear juice was diluted with $50 \mathrm{ml}$ distilled water and titrated to $\mathrm{pH} 8.1$ with $0.1 \mathrm{~N}$ sodium hydroxide. TA was expressed as $\mathrm{g}$ malic acid/ $\mathrm{kg}^{-1}$ of juice. Soluble solids content, expressed as 
${ }^{\circ}$ Brix, was measured using a tabletop refractometer (ATAGO, Japan) at $20^{\circ} \mathrm{C}$. Six pears were used per time interval.

\section{Descriptive sensory evaluation}

Twenty sensory descriptors, as defined in Table 1, were developed and used by a trained descriptive sensory evaluation panel $(n=12)$ to determine the sensory quality of uncoated and kafirin coated 'Packham's Triumph' pears stored for 24 days at $20^{\circ} \mathrm{C}$. Panel selection was based on the sensitivity of the candidates to the basic tastes (sweet, sour, bitter, salty) and on their ability to distinguish between pears at different stages of ripeness (days $0,3,7,10,14$ ). Sensory qualities of uncoated and coated pears were assessed every three days over a period of 24 days. A nine-point intensity scale (1 minimum, 9 maximum) was used to evaluate the sensory descriptors. Samples were evaluated in duplicate using peeled pears for all evaluations except for external appearance and aroma. A control sample in the eat-ripe state (ripened for 7 days at $20^{\circ} \mathrm{C}$ as defined by the South African fruit industry) was also assessed. Within the context of this research, the terms shelf life and eat-ripe stage are defined as follows. Shelf-life means the length of time in days where pears maintain eatripe quality when a number of different physico-chemical and sensory quality parameters are considered. Three different ripeness stages can be identified: Unripe - where statistically the sensory parameter scores were significantly lower than the scores of the eat-ripe samples (7 days ripened at $20{ }^{\circ} \mathrm{C}$ ); Eat ripe - where statistically the sensory parameter scores were not significantly different from the scores of the eat-ripe samples; Over-ripe - where statistically 
the sensory parameters scores were significantly higher than the scores of the eat-ripe samples ( 7 days ripened at $20^{\circ} \mathrm{C}$ ).

\section{Statistical analyses}

Analysis of variance (ANOVA) followed by the LSD multiple comparison test were performed at a $95 \%$ confidence limit $(p<0.05)$ using STATISTICA $^{\circledR}$ (version 6, StaSoft, 2003) software. Univariate analysis of the descriptive sensory evaluation data indicated that only 15 of the 20 sensory attributes (i.e. analysed indicated significant differences $(p<0.05)$ between the coated and uncoated pears over the 24 day storage period. The non-significant $(p>0.05)$ attributes (i.e. external fermented aroma, white powdery appearance, juiciness, sour, bitter, pear-like flavour, sweetness and astringent flavour) were excluded from further analyses. Principal component classification analysis (PCA) including the sensory (for appearance) and physico-chemical characteristics was conducted using a correlation matrix with treatments in rows and characteristics in columns.

\section{RESULTS AND DISCUSSION}

\section{Respiration rate}

The respiration patterns of the coated and uncoated pears (Fig. 1) exhibited a sharp incline (climacteric phase) that lead to a clear climacteric peak (optimum physiological ripeness) on day four. The respiration rate of the coated pears $\left(28.6 \pm 2.8 \mathrm{mg} \mathrm{CO}_{2} \mathrm{~kg}^{-1} \mathrm{~h}^{-1}\right)$ at the climacteric peak was significantly $(\mathrm{p}<0.05)$ lower than that of the uncoated pears $\left(41.4 \pm 2.2 \mathrm{mg} \mathrm{CO}_{2} \mathrm{~kg}^{-1} \mathrm{~h}^{-1}\right)$. The peak was followed by a steady decline (start of senescent phase) in respiration rate for both coated and uncoated pears. Such respiratory patterns are typical of 
aerobic respiration in climacteric fruit ${ }^{17}$. A critical requirement for an edible coating is that aerobic respiration and typical ripening of the fruit should occur albeit at a retarded rate $^{23}$. Since the respiration pattern of the coated fruit followed that of the uncoated fruit, the kafirin coating allowed the fruit to respire aerobically.

The time taken for pears to reach a climacteric peak, is in the range of 78 days ${ }^{4,5}$. According to the respiration data, both the coated and uncoated pears reached their climacteric peak earlier and so reached physiological ripeness faster than may have been expected during this study. The storage history of the pears prior to the start of the experiment may have contributed to the accelerated physiological ripening rate of the pears. Refrigeration of the pears at $0^{\circ} \mathrm{C}$ for one week under regular atmosphere prior to the start of the study may also have increased pear ripening. Refrigeration would have retarded but not prevented fruit ripening by reducing the rate of metabolism ${ }^{24}$. Cold storage of pears prior to wax coating has been found to increase pear ripening, due to the pears entering the climacteric (rapid ripening) phase at the time of coating ${ }^{4}$. Coating of more mature pears resulted in the pears ripening faster and exhibiting a shorter shelf-life than the freshly harvested pears, which were in the pre-climacteric phase at the time of wax-coating.

In addition, temperature equilibration of the pears at $20^{\circ} \mathrm{C}$ for $16 \mathrm{~h}$ before application of the coating to the selected pears, may have further contributed to the accelerated ripening rate of all the fruit by inducing ripening. This practice has been followed by other workers without reported negative affects on fruit quality ${ }^{7,1}$. 
Overall, the average respiration rate of the kafirin-coated pears $(20.9 \mathrm{mg}$ $\left.\mathrm{CO}_{2} \mathrm{~kg}^{-1} \mathrm{~h}^{-1}\right)$ (Fig. 1) was significantly $(\mathrm{p}<0.001)$ lower than that of the uncoated pears (30.9 $\mathrm{mg} \mathrm{CO}_{2} \mathrm{~kg}^{-1} \mathrm{~h}^{-1}$ ) over the 24 day period. During aerobic respiration, the respiration rate is dependant on the amount of $\mathrm{O}_{2}$ consumed for the oxidation of carbohydrates, which are subsequently metabolised to $\mathrm{CO}_{2}{ }^{25}$. The respiration rates of fruits decrease in response to reduced levels of $\mathrm{O}_{2}{ }^{26}$. According to Sfakiotakis and Dilley $(1973)^{27}$, reduction in $\mathrm{O}_{2}$ uptake is followed by reduced respiration rate as a primary metabolic response to low $\mathrm{O}_{2}$ concentrations. Free-standing kafirin films are known to be good gas barriers ${ }^{14}$ and so it is likely that the kafirin coating was capable of limiting $\mathrm{O}_{2}$ availability to the pears (Fig. 1) resulting in the observed lower respiration rate than the uncoated pears.

Eksteen and Ginsburg $(1977)^{28}$ considered that Bon Cretien' pears are eat-ripe at the climacteric peak and that senescence followed the eat-ripe phase. However, our descriptive sensory data (Table 2) indicated that eatripeness of 'Packham's Triumph pears' for both uncoated and coated samples are reached only at a later stage when compared with respiration data (Fig. 1). The uncoated pears reached eat-ripeness after 7 days of ripening, in agreement with the SA fruit industry standards, whereas the coated pears reached eatripeness between 10 and 24 days, depending on the sensory descriptor.

The slope of the curves for respiration rates after day four (start of senescent phase) for the coated pears appeared to be less steep when compared to that of the uncoated pears. This indicated that senescence and deterioration may have progressed at a slower rate in the coated pears. Thus, although the kafirin coating may not have retarded the climacteric phase or 
delayed the reaching of the climacteric peak, it may have retarded the senescence phase by limiting the $\mathrm{O}_{2}$ availability to the coated pears. It also retarded the time needed to attain the eat-ripe stage. Furthermore, eatripeness was maintained for less than 3 days for the uncoated and between 7 and 14 days for the coated samples (Table 2).

\section{Moisture loss and shrivelling}

Both the coated and uncoated pears showed a significant $(p<0.05)$ loss of mass (up to $10 \%$ ), during storage at $20^{\circ} \mathrm{C}$ over a period of 24 days. This mass loss was used as an indication of moisture loss through transpiration. Moisture loss was expected as the metabolic activity of pears at the typical ripening temperature $\left(20^{\circ} \mathrm{C}\right)$ would be high and the ambient relative humidity, low (35$45 \%)$. However, there was no significant $(p>0.05)$ difference in moisture loss between the coated and uncoated pears. In fact, the coated pears appeared to shrivel faster (over the entire pear surface) than the uncoated pears after more than 10 days of ripening at $20^{\circ} \mathrm{C}(35-45 \% \mathrm{RH})$ (Fig. 2). In part, this may be due to blemishes or stains. Although kafirin is a hydrophobic protein, free-

standing kafirin films do not have good water barrier properties ${ }^{14,29}$. It is suggested that the more severe shrivelling shown by the kafirin coated pears was caused by the elasticity of the kafirin coating squeezing the pear, on moisture loss, in a similar way to a partially deflated balloon within an elastic net. These results show that the kafirin coating was not an effective moisture barrier and did not reduce moisture loss and shrivelling.

As would be expected, moisture loss measurement grouped with the visual sensory appearance attributes, wrinkled skin and presence of blemishes 
when examined by PCA (Fig. 3a). Skin shrivelling/wrinkling and the occurrence of blemishes increased as moisture loss increased. Although principal component 2 (Fig. 3) only described $10 \%$ of the total variance in appearance, it separated the pears on the basis of days of ripening and presence of coating (Fig. 3b). The pears can be considered in 3 groups. Group A, consisted of uncoated fruit up to day 3 and coated fruit up to day 10. Group A appeared to have none of the visual sensory attributes associated with ripe fruit. Group B consisted of uncoated fruit from day 7 to day 24 and did exhibit visual sensory attributes associated with ripe fruit. Group $\mathrm{C}$ consisted of coated fruit from day 14 to day 24 . From day 14 onwards the coated pears appeared more shrivelled than the uncoated pears for reasons described above.

\section{Colour}

Eat-ripe, 'Packham's Triumph' pears typically have a green or green-yellow skin colour. A yellow 'Packham's Triumph' pear is considered over-ripe and past it's best eating quality. Principal component 1 (Fig. 3) described $83 \%$ of the variance in pear appearance during ripening and reflected mainly the colour differences between the coated and uncoated pears. Group A were characterised by having a green background, indicating their unripe state, whereas pears in Groups B and C (particularly uncoated pears ripened for 7 days or more) appeared to be visually riper. The negative correlation between the $a^{*}$ values (de-greening) and the observed green background (Fig. 3) was expected. Green colour recedes as ripening of the fruit proceeds coinciding with increased $a^{*}$ values for both coated and uncoated pears. However, the rate at which the de-greening occurred was much faster in the uncoated pears 
than in the coated pears. The $a^{*}$ values of the uncoated pears showed that significant $(p<0.05)$ de-greening occurred between days 3 and 17 , whilst the coated pears still had a negative $a^{*}$ value on day 17 . Coated pears still had a similar green background after 24 days of ripening than eat-ripe samples. The significant $(p<0.05)$ increase in $b^{*}$ values of the uncoated pears and the positive correlation between $b^{*}$ values and observed yellow background indicated that yellowing of uncoated pears occurred between day 3 and 7 . The uncoated pears were fully yellow by day 10 . As stated, the coated pears degreened at a slower rate than the uncoated pears. The lack of yellowing of the coated pears was also seen in the results of the descriptive sensory data.

The delay in skin colour change of the coated pears may be due to the gas barrier properties of the kafirin coating. Colour change in wax-coated pears has been shown to be sensitive to small changes in the internal $\mathrm{O}_{2}$ concentration $^{30}$. When the wax coating thickness was increased, the internal $\mathrm{O}_{2}$ concentration of the pears decreased resulting in a delay in colour change. The reduced respiration rate of the coated pears (Fig. 1) is consistent with the possibility that the kafirin coating was able to reduce the amount of $\mathrm{O}_{2}$ available from the atmosphere, to the pears during respiration. Hence, the retarded colour change in the coated pears may have been due to the lower internal $\mathrm{O}_{2}$ levels of the coated pears when compared to that of the uncoated pears.

\section{Flesh firmness}

Texture measurements of external and internal flesh firmness decreased significantly $(p<0.05)$ between days 0 and 3 for both the coated and uncoated pears. This was in agreement with changes in the sensory attributes, i.e. 
increase in softness and decrease in crispiness over the same period (Table 2). These textural changes coincided with the climacteric phase (days 0 to 4 ) of the respiration rate data (Fig. 1). Rapid textural changes in climacteric fruit typically occur during the climacteric phase ${ }^{25}$. Between days 3 and 10 the rate of textural change of external and internal flesh firmness was less than that between 0 and 3 days (climacteric phase) for both the coated and uncoated pears and coincided with the onset of senescence (after the climacteric peak) according to the respiration rate data (Fig. 1). Again this was confirmed by the sensory data (Table 2). The rate of fruit flesh softening during senescence is typically less than during the climacteric phase ${ }^{25}$. Generally, the coated pears were slightly firmer than the uncoated pears over this period but variation in fruit firmness of individual fruits was high. Beyond day 10 to the end of the shelf-life, objective texture measurements showed no difference between treatments or between days of storage. The descriptive sensory panel perceived coated pears to be more firm and crisp than uncoated pears up to the end of the shelflife study and so appeared more sensitive to textural changes than objective measurements.

Overall, the kafirin coating appeared to have a less dramatic effect on flesh firmness than on skin colour. This is in agreement with Amarante et al. $(2001 \mathrm{a})^{4}$, who found that during storage of wax-coated pears at $20^{\circ} \mathrm{C}$, softening and respiration rates were not delayed as dramatically as colour change, when compared to un-waxed pears. This was attributed to changes in internal gas concentrations due to the coating. The wax coating modified the internal $\mathrm{O}_{2}$ concentrations more than the internal $\mathrm{CO}_{2}$ concentrations during storage at $20^{\circ} \mathrm{C}$. Textural changes were thought to be sensitive to changes in $\mathrm{CO}_{2}$ 
concentration, whereas colour changes were related to internal $\mathrm{O}_{2}$ concentrations. Due to its hydrophobic nature, it is suggested that the kafirin coating behaved in a similar way to the wax coating. Thus a small change in internal $\mathrm{CO}_{2}$ concentrations of the pears due to the kafirin coating would result in small textural differences between the coated and uncoated pears as observed.

\section{Flavour and aroma}

The total soluble solids content (SSC) of all the pears increased and the titratable acidity (TA) decreased with time as is typical during fruit ripening ${ }^{17}$. Overall, there were no significant $(p>0.05)$ differences between the coated and uncoated pears with respect to TA or SSC content during the 24 day storage period.

Considering the sensory data, during the first three days of storage both the coated and uncoated pears had a green aroma with no fermented flavour (Table 2). The uncoated pears developed a sweet, pear like aroma by day 7 but it was not until day 10 that the coated pears developed this aroma profile. The change in aroma and taste of the uncoated pears coincided with an increase in titratable acidity after day 10 . This increase in acidity may have been the result of the loss of cell integrity during senescence and the subsequent mixing of the cell contents (sugars, acids, flavour components). By day 14 , the sensory data (Table 2 ) indicated that the coated and uncoated pears developed a fermented flavour, which intensified as the storage duration increased. This fermented flavour was more pronounced in the uncoated pears when compared to the coated pears (Table 2). The less distinctive fermented 
flavour in the coated pears may have been the result of retarded flavour development due to the reduced internal $\mathrm{O}_{2}$ levels brought about by the gas barrier properties of the coating.

\section{CONCLUSIONS}

Kafirin coating, when applied to 'Packham's Triumph' pears was able to decrease the respiration rate and retard the progression of senescence of the pears due to the good gas barrier properties of the coating. However, as storage time increased the coated pears wrinkled due to the poor moisture barrier properties of the coating. Thus whilst the eat-ripe quality of the pears was extended by the use of the kafirin coating, the appearance of the fruit was unacceptable. Further work is needed to improve the water barrier properties of the kafirin coating by incorporating a wax or triglyceride into the coating formulation or more simply by applying a kafirin coating to waxed fruit.

\section{ACKNOWLEDGEMENTS}

This project was funded by the European Commission (Enviropak project, INCO2: ICA4-CT-2001-10062) and CSIR Biosciences.

\section{REFERENCES}

1. Drake SR, Cavalieri R and Kupferman EM, Quality attributes of D’Anjou pears after different wax drying temperatures and refrigerated storage. J Food Quality 14: 455-465 (1991).

2. Drake SR, Fellman JK and Nelson JW, Postharvest use of sucrose polyesters for extending the shelf-life of stored Golden Delicious apples. J Food Sci 52: 1283-1285 (1987). 
3. Park HJ, Development of advanced edible coatings for fruits. Trends Food Sci Tech 10: 254-260 (1999).

4. Amarante C, Banks $\mathrm{NH}$ and Ganesh S, Characterising ripening behaviour of coated pears in relation to fruit internal atmosphere. Postharv Biol Technol 23: 51-59 (2001a).

5. Amarante C, Banks N and Ganesh S, Effects of coatings concentration, ripening stage, water status and fruit temperature on pear susceptibility to friction discolouration. Postharv Biol Technol 21: 238-290 (2001b).

6. Park HJ, Chinnan MS and Shewfelt RL, Edible corn-zein film coatings to extend storage life of tomatoes. J Food Process Pres 18: 317-331 (1994).

7. Bai J, Alleyne V, Hagenmaier RD, Mattheis JP and Baldwin EA, Formulation of zein coatings for apples (Malus domestica Borkh). Postharv Biol Technol 28: 259-268 (2003).

8. Shull JM, Watterson JJ and Kirleis AW, Proposed nomenclature for the alcohol-soluble proteins (kafirins) of Sorghum bicolour (L. Moench) based on molecular weight, solubility and structure. J Agric Food Chem 39: 83-87 (1991).

9. DeRose R, Ma OP, Kwon IS, Hasnain SE, Klassy RC and Hall T, Characterization of the kafirin gene family from sorghum reveals extensive homology with zein from maize. Plant Mol Biol 12: 245-256 (1989).

10. Belton PS, Delgadillo I, Halford NG and Shewry PR, Kafirin structure and functionality. J Cereal Sci 44: 272-286 (2006). 
11. Ciacci C, Maiuri L, Caporaso N, Bucci C, Del Giudice L., Massardo, DR, Pontieri P, Di Fonzo N, Bean SR, loerger B and Londei M, Clin Nutr 26: 799-805 (2007).

12. Buffo RA, Weller $\mathrm{CL}$ and Gennadios A, Films from laboratoryextracted kafirin. Cereal Chem 74: 473-475 (1997).

13. Da Silva LS; Taylor JRN, Physical, mechanical, and barrier properties of kafirin films from red and white sorghum milling fractions. Cereal Chem 82: 9-14 (2005).

14. Emmambux $M N$; Stading $M$ and Taylor JRN, Sorghum kafirin film property modification with hydrolysable and condensed tannins. $J$ Cereal Sci 40: 127-135 (2004).

15. Gao C, Taylor J, Wellner N, Byaruhanga YB, Parker ML, Mills, ENC and Belton PS, Effect of preparation conditions on protein secondary structure and biofilm formation of kafirin. J Agric Food Chem 53: 306312 (2005).

16. Emmambux NE and Taylor JRN, 2003. Sorghum kafirin interaction with various phenolic compounds. J Sci Food Agric 83: 402-407 (2003).

17. Von Mollendorff L, Physiological changes in fruit during the development and ripening, in Integrated Management of Post-harvest Quality, ed. by Combrink JC, ARC Infruitec, Nietvoorbij, Stellenbosch, pp. 33-38 (1996).

18. Saltveit ME, Effect of alcohols and their interaction with ethylene on the ripening of epidermal pericarp discs of tomato fruit. Plant Physiol 90: 167-174 (1989). 
19. Yanuriati A, Savage GP and Rowe RN, The effect of ethanol treatment on the metabolism, shelf life and quality of stored tomatoes at different maturities and temperature. J Sci Food Agric 79: 9951002 (1999).

20. Suzuki $\mathrm{Y}, \mathrm{Uji} \mathrm{T}$ and Terai $\mathrm{H}$, Inhibition of senescence in broccoli florets with ethanol vapor from alcohol powder. Postharv Biol Technol 31: 177-182 (2004).

21. Ritenour MA, Mangrich ME, Beaulieu JC, Rab A and Saltveit ME, Ethanol effects on the ripening of climacteric fruit. Postharv Biol Technol 12: 35-42 (1997).

22. De Man JM, Principles of Food Chemistry. New York/Heidelberg, Springer-Verlag, pp 201 (1980).

23. Baldwin EA, Edible coatings for fresh fruits and vegetables: past, present, and future, in Edible Coatings and Films to Improve Food Quality, ed. by Krochta JM, Baldwin EA and Nisperos-Carriedo MO, Technomic Publishing Co, Lancaster, PA, pp 25-64 (1994).

24. Findlay JS and Combrink JC, Cold chain management, in Integrated Management of Post-harvest Quality, ed. by Combrink JC, ARC Infruitec, Nietvoorbij, Stellenbosch, pp 79-90 (1996).

25. Wills R, Lee TH, Graham D, McGlasson WB and Hall EG (eds), Postharvest, An introduction to the Physiology and Handling of Fruits and Vegetables. AVI Publishing Co. Inc., Westport, CT (1981).

26. Kader AA, Biochemical and physiological basis for effects of controlled and modified atmospheres on fruits and vegetables. Food Technol 40: (5), 99-104 (1986). 
27. Sfakiotakis EM and Dilley DR, Induction of autocatalytic ethylene production in apple fruits by propylene in relation to maturity and oxygen. J Am Soc Hort Sci 98: 504-508 (1973).

28. Eksteen GJ and Ginsburg L, Respiration and senescence of pears in storage. Deciduous Fruit Grower 27: 46-49 (1977).

29. Gillgren $T$ and Stading M, Mechanical and barrier properties of avenin, kafirin and zein films. Food Biophys 3: 287-294 (2008).

30. Amarante $\mathrm{C}$ and Banks $\mathrm{NH}$, Ripening behaviour, postharvest quality, and physiological disorders of coated pears (Pyrus communis). New $\begin{array}{llllll}\text { Zeal J } & \text { Crop } & \text { Hort } & \text { 39-59 } & \text { (2002). }\end{array}$ 
Table 1. Sensory descriptors, scales and definitions used to describe the sensory properties of the pears

\begin{tabular}{|c|c|}
\hline Descriptor and Scale & Definition \\
\hline \multicolumn{2}{|l|}{ External appearance } \\
\hline Green background & $\begin{array}{l}\text { Refers to the depth of green colour in the background of } \\
\text { the skin of the pear }\end{array}$ \\
\hline Yellow background & $\begin{array}{l}\text { Refers to the depth of yellow colour in the background } \\
\text { of the skin of the pear }\end{array}$ \\
\hline Presence of blemishes & $\begin{array}{l}\text { Extent of black or brown blemishes on the outer surface } \\
\text { of pear }\end{array}$ \\
\hline Wrinkled skin & Extent of wrinkled skin on surface of pear \\
\hline Extent of ripeness & Extent of overall visual ripeness of pears \\
\hline $\begin{array}{l}\text { White powdery } \\
\text { appearance }\end{array}$ & $\begin{array}{l}\text { Presence of white powdery deposits on the surface of } \\
\text { the pears }\end{array}$ \\
\hline $\begin{array}{l}\text { Internal appearance } \\
\text { Juicy appearance }\end{array}$ & $\begin{array}{l}\text { Extent of juicy appearance of the inner cut surface of } \\
\text { the pear }\end{array}$ \\
\hline
\end{tabular}

Internal and external aroma (same descriptors used for both)

Green aroma

Similar to the aroma of unripe pear skins

Pear-like aroma

Pear-like aroma intensity associated with fresh ripe pears

Fermented/alcoholic Aroma associated with fermented pears/pear juice aroma

Texture

Softness

Juiciness

Crispness

Extent of softness of pear while chewing

Amount of juice produced during chewing

How crisp the pear seems during chewing - e.g. a carrot would be crispy, making a characteristic crunchy sound while chewing

\section{Flavour}

Descriptor and Scale Definition

Sweet

A basic taste characterised by a solution of fructose

Sour

Bitter

Astringent

Green

A basic taste characterised by the solution of an organic acid i.e. malic acid

A primary taste characterised by a solution of caffeine

Fermented or alcoholic

Pear-like flavour

Associated with a dry feeling in mouth as produced by grape skins

Similar to the flavour of unripe pear skins

Aroma associated with fermented pears/pear juice

Pear-like flavour intensity associated with fresh ripe pears 
Table 2. Effect of a $2 \%(w / w)$ kafirin coating on selected aroma, texture and flavour characteristics of Packham's Triumph pears stored at $20^{\circ} \mathrm{C}(35-45 \% \mathrm{RH})$ for 24 days

\begin{tabular}{|c|c|c|c|c|}
\hline Characteristic & $\begin{array}{c}\text { Storage } \\
\text { (days) }\end{array}$ & Uncoated & Coated & Eat-ripe control \\
\hline \multicolumn{5}{|c|}{ External aroma } \\
\hline \multirow[t]{8}{*}{ Green aroma } & 0 & $7.6^{\mathrm{a}} \pm 0.9$ & $6.7^{\mathrm{a}} \pm 2.0$ & $4.2^{b} \pm 2.4$ \\
\hline & 3 & $6.3^{\mathrm{a}} \pm 2.0$ & $5.7^{\mathrm{a}} \pm 2.2$ & $2.8^{\mathrm{b}} \pm 2.0$ \\
\hline & 7 & $2.1^{\mathrm{a}} \pm 1.7$ & $4.7^{b} \pm 2.3$ & $2.4^{\mathrm{a}} \pm 1.4$ \\
\hline & 10 & $1.9^{\mathrm{a}} \pm 1.5$ & $3.9^{\mathrm{b}} \pm 2.1$ & $3.0^{\mathrm{a}} \pm 2.1$ \\
\hline & 14 & $1.2^{\mathrm{a}} \pm 0.4$ & $2.3^{\mathrm{b}} \pm 1.7$ & $3.5^{c} \pm 2.1$ \\
\hline & 17 & $1.5^{\mathrm{a}} \pm 1.1$ & $4.3^{b} \pm 2.5$ & $4.2^{\mathrm{b}} \pm 2.2$ \\
\hline & 21 & $1.5^{\mathrm{a}} \pm 1.2$ & $2.7^{b} \pm 2.1$ & $3.6^{\mathrm{b}} \pm 2.2$ \\
\hline & 24 & $1.7^{\mathrm{a}} \pm 1.5$ & $3.3^{\mathrm{b}} \pm 2.7$ & $5.3^{c} \pm 2.1$ \\
\hline \multirow[t]{8}{*}{ Pear-like aroma } & 0 & $1.9^{\mathrm{a}} \pm 0.9$ & $2.6^{\mathrm{a}} \pm 1.7$ & $5.3^{b} \pm 2.0$ \\
\hline & 3 & $2.9^{a} \pm 1.6$ & $4.6^{b} \pm 1.9$ & $6.8^{\mathrm{c}} \pm 1.5$ \\
\hline & 7 & $6.6^{\mathrm{a}} \pm 2.0$ & $4.8^{\mathrm{b}} \pm 2.1$ & $6.3^{\mathrm{a}} \pm 1.7$ \\
\hline & 10 & $6.5^{\mathrm{a}} \pm 1.8$ & $5.5^{\mathrm{a}} \pm 2.2$ & $6.5^{\mathrm{a}} \pm 1.9$ \\
\hline & 14 & $6.7^{\mathrm{a}} \pm 1.8$ & $6.5^{\mathrm{a}} \pm 1.7$ & $6.3^{\mathrm{a}} \pm 1.6$ \\
\hline & 17 & $6.1^{\mathrm{a}} \pm 2.4$ & $5.0^{\mathrm{a}} \pm 2.3$ & $5.5^{\mathrm{a}} \pm 2.0$ \\
\hline & 21 & $5.4^{\mathrm{a}} \pm 2.5$ & $5.3^{\mathrm{a}} \pm 2.0$ & $6.0^{\mathrm{a}} \pm 1.9$ \\
\hline & 24 & $5.5^{\mathrm{a}} \pm 2.7$ & $5.4^{\mathrm{a}} \pm 2.1$ & $5.1^{\mathrm{a}} \pm 2.3$ \\
\hline \multicolumn{5}{|c|}{ Internal aroma } \\
\hline \multirow[t]{8}{*}{ Green aroma } & 0 & $7.6^{\mathrm{a}} \pm 0.9$ & $6.7^{\mathrm{a}} \pm 2.0$ & $4.2^{b} \pm 2.4$ \\
\hline & 3 & $6.3^{\mathrm{a}} \pm 2.0$ & $5.7^{\mathrm{a}} \pm 2.2$ & $2.8^{\mathrm{b}} \pm 2.0$ \\
\hline & 7 & $2.1^{\mathrm{a}} \pm 1.7$ & $4.7^{\mathrm{b}} \pm 2.3$ & $2.4^{\mathrm{a}} \pm 1.4$ \\
\hline & 10 & $1.9^{\mathrm{a}} \pm 1.5$ & $3.9^{\mathrm{b}} \pm 2.1$ & $3.0^{\mathrm{a}} \pm 2.1$ \\
\hline & 14 & $1.2^{\mathrm{a}} \pm 0.4$ & $2.3^{\mathrm{b}} \pm 1.7$ & $3.5^{\mathrm{c}} \pm 2.1$ \\
\hline & 17 & $1.5^{\mathrm{a}} \pm 1.1$ & $4.3^{b} \pm 2.5$ & $4.2^{\mathrm{b}} \pm 2.2$ \\
\hline & 21 & $1.5^{\mathrm{a}} \pm 1.2$ & $2.7^{b} \pm 2.1$ & $3.6^{\mathrm{b}} \pm 2.2$ \\
\hline & 24 & $1.7^{\mathrm{a}} \pm 1.5$ & $3.3^{\mathrm{b}} \pm 2.7$ & $5.3^{c} \pm 2.1$ \\
\hline \multirow[t]{8}{*}{ Pear-like aroma } & 0 & $1.9^{\mathrm{a}} \pm 0.9$ & $2.6^{\mathrm{a}} \pm 1.7$ & $5.3^{b} \pm 2.0$ \\
\hline & 3 & $2.9^{\mathrm{a}} \pm 1.6$ & $4.6^{b} \pm 1.9$ & $6.8^{\mathrm{c}} \pm 1.5$ \\
\hline & 7 & $6.6^{\mathrm{a}} \pm 2.0$ & $4.8^{\mathrm{b}} \pm 2.1$ & $6.3^{\mathrm{a}} \pm 1.7$ \\
\hline & 10 & $6.5^{\mathrm{a}} \pm 1.8$ & $5.5^{\mathrm{a}} \pm 2.2$ & $6.5^{\mathrm{a}} \pm 1.9$ \\
\hline & 14 & $6.7^{\mathrm{a}} \pm 1.8$ & $6.5^{\mathrm{a}} \pm 1.7$ & $6.3^{\mathrm{a}} \pm 1.6$ \\
\hline & 17 & $6.1^{\mathrm{a}} \pm 2.4$ & $5.0^{\mathrm{a}} \pm 2.3$ & $5.5^{\mathrm{a}} \pm 2.0$ \\
\hline & 21 & $5.4^{\mathrm{a}} \pm 2.5$ & $5.3^{\mathrm{a}} \pm 2.0$ & $6.0^{\mathrm{a}} \pm 1.9$ \\
\hline & 24 & $5.5^{\mathrm{a}} \pm 2.7$ & $5.4^{\mathrm{a}} \pm 2.1$ & $5.1^{\mathrm{a}} \pm 2.3$ \\
\hline \multirow[t]{6}{*}{ Fermented aroma } & 0 & $1.1^{\mathrm{a}} \pm 0.5$ & $1.5^{\mathrm{a}} \pm 1.0$ & $2.2^{\mathrm{b}} \pm 1.9$ \\
\hline & 3 & $1.2^{\mathrm{a}} \pm 0.7$ & $1.4^{\mathrm{a}} \pm 1.2$ & $2.4^{\mathrm{b}} \pm 1.8$ \\
\hline & 7 & $3.3^{\mathrm{a}} \pm 2.1$ & $2.0^{\mathrm{a}} \pm 1.5$ & $2.8^{\mathrm{a}} \pm 2.4$ \\
\hline & 10 & $3.2^{\mathrm{a}} \pm 2.7$ & $1.8^{\mathrm{a}} \pm 1.6$ & $2.5^{\mathrm{a}} \pm 2.2$ \\
\hline & 14 & $3.9^{\mathrm{b}} \pm 2.6$ & $3.7^{\mathrm{b}} \pm 2.8$ & $2.2^{\mathrm{a}} \pm 2.2$ \\
\hline & 17 & $4.3^{b} \pm 2.7$ & $3.1^{\mathrm{ab}} \pm 2.4$ & $2.3^{\mathrm{a}} \pm 2.2$ \\
\hline
\end{tabular}




\begin{tabular}{|c|c|c|c|c|}
\hline Characteristic & $\begin{array}{c}\text { Storage } \\
\text { (days) }\end{array}$ & Uncoated & Coated & Eat-ripe control \\
\hline & 21 & $5.3^{b} \pm 2.7$ & $4.3^{b} \pm 2.7$ & $2.0^{\mathrm{a}} \pm 1.9$ \\
\hline & 24 & $5.0^{\mathrm{b}} \pm 2.9$ & $3.5^{\mathrm{b}} \pm 2.7$ & $1.9^{\mathrm{a}} \pm 2.1$ \\
\hline \multicolumn{5}{|c|}{ Texture } \\
\hline \multirow[t]{8}{*}{ Softness } & 0 & $1.5^{\mathrm{a}} \pm 0.7$ & $2.0^{\mathrm{a}} \pm 1.2$ & $6.5^{\mathrm{b}} \pm 1.7$ \\
\hline & 3 & $5.4^{\mathrm{a}} \pm 1.1$ & $5.2^{\mathrm{a}} \pm 1.2$ & $7.3^{\mathrm{b}} \pm 1.1$ \\
\hline & 7 & $7.6^{\mathrm{a}} \pm 1.0$ & $6.8^{\mathrm{b}} \pm 1.7$ & $7.9^{\mathrm{a}} \pm 1.0$ \\
\hline & 10 & $8.4^{\mathrm{b}} \pm 0.7$ & $7.5^{\mathrm{a}} \pm 1.7$ & $7.5^{\mathrm{a}} \pm 1.2$ \\
\hline & 14 & $8.3^{b} \pm 0.9$ & $7.8^{\mathrm{ab}} \pm 1.1$ & $7.4^{\mathrm{a}} \pm 1.1$ \\
\hline & 17 & $8.5^{\mathrm{b}} \pm 0.7$ & $7.3^{\mathrm{a}} \pm 1.8$ & $7.0^{\mathrm{a}} \pm 1.5$ \\
\hline & 21 & $8.4^{\mathrm{b}} \pm 1.1$ & $7.2^{\mathrm{a}} \pm 1.9$ & $7.2^{\mathrm{a}} \pm 1.2$ \\
\hline & 24 & $8.2^{\mathrm{b}} \pm 0.8$ & $7.2^{\mathrm{a}} \pm 2.0$ & $6.6^{\mathrm{a}} \pm 1.0$ \\
\hline \multirow[t]{8}{*}{ Crispness } & 0 & $8.1^{\mathrm{a}} \pm 1.4$ & $7.5^{\mathrm{a}} \pm 1.8$ & $2.6^{b} \pm 2.1$ \\
\hline & 3 & $4.1^{\mathrm{a}} \pm 1.9$ & $4.0^{\mathrm{a}} \pm 1.8$ & $1.8^{\mathrm{b}} \pm 1.4$ \\
\hline & 7 & $2.0^{\mathrm{a}} \pm 1.9$ & $2.4^{\mathrm{a}} \pm 1.9$ & $1.9^{\mathrm{a}} \pm 1.4$ \\
\hline & 10 & $1.3^{\mathrm{a}} \pm 1.0$ & $2.7^{\mathrm{b}} \pm 2.1$ & $1.7^{\mathrm{a}} \pm 1.5$ \\
\hline & 14 & $1.4^{\mathrm{a}} \pm 0.8$ & $1.7^{\mathrm{a}} \pm 1.6$ & $1.8^{\mathrm{a}} \pm 1.0$ \\
\hline & 17 & $1.2^{\mathrm{a}} \pm 0.6$ & $2.9^{\mathrm{b}} \pm 2.6$ & $2.2^{\mathrm{ab}} \pm 1.4$ \\
\hline & 21 & $1.3^{\mathrm{a}} \pm 0.8$ & $2.0^{\mathrm{a}} \pm 1.8$ & $2.1^{\mathrm{a}} \pm 1.4$ \\
\hline & 24 & $1.4^{\mathrm{a}} \pm 1.2$ & $2.6^{\mathrm{b}} \pm 2.3$ & $2.8^{\mathrm{b}} \pm 1.7$ \\
\hline \multicolumn{5}{|c|}{ Flavour } \\
\hline \multirow[t]{8}{*}{ Green flavour } & 0 & $6.6^{\mathrm{a}} \pm 2.1$ & $5.4^{\mathrm{a}} \pm 2.5$ & $2.9^{b} \pm 2.1$ \\
\hline & 3 & $4.3^{\mathrm{a}} \pm 2.0$ & $3.8^{\mathrm{a}} \pm 2.2$ & $1.6^{\mathrm{b}} \pm 1.0$ \\
\hline & 7 & $1.3^{\mathrm{a}} \pm 0.6$ & $3.3^{b} \pm 2.3$ & $1.3^{\mathrm{a}} \pm 0.8$ \\
\hline & 10 & $1.3^{\mathrm{a}} \pm 0.7$ & $2.4^{\mathrm{b}} \pm 1.8$ & $1.7^{\mathrm{ab}} \pm 1.4$ \\
\hline & 14 & $1.2^{\mathrm{a}} \pm 0.4$ & $1.3^{\mathrm{a}} \pm 0.7$ & $2.1^{\mathrm{b}} \pm 1.8$ \\
\hline & 17 & $1.6^{\mathrm{a}} \pm 1.5$ & $2.5^{\mathrm{a}} \pm 2.4$ & $2.5^{\mathrm{a}} \pm 1.9$ \\
\hline & 21 & $1.2^{\mathrm{a}} \pm 0.7$ & $1.4^{\mathrm{a}} \pm 0.8$ & $2.6^{\mathrm{b}} \pm 1.9$ \\
\hline & 24 & $1.3^{\mathrm{a}} \pm 1.0$ & $2.1^{\mathrm{a}} \pm 1.8$ & $3.2^{\mathrm{b}} \pm 2.2$ \\
\hline \multirow[t]{8}{*}{ Fermented flavour } & 0 & $1.1^{\mathrm{a}} \pm 0.5$ & $1.2^{\mathrm{a}} \pm 0.7$ & $1.9^{\mathrm{b}} \pm 1.3$ \\
\hline & 3 & $1.4^{\mathrm{a}} \pm 1.0$ & $1.3^{\mathrm{a}} \pm 0.9$ & $2.3^{\mathrm{b}} \pm 1.9$ \\
\hline & 7 & $2.9^{\mathrm{b}} \pm 2.1$ & $1.5^{\mathrm{a}} \pm 1.1$ & $2.4^{\mathrm{ab}} \pm 1.6$ \\
\hline & 10 & $2.9^{\mathrm{a}} \pm 2.2$ & $2.3^{\mathrm{a}} \pm 2.0$ & $2.3^{\mathrm{a}} \pm 1.7$ \\
\hline & 14 & $3.8^{\mathrm{b}} \pm 2.4$ & $3.5^{\mathrm{ab}} \pm 2.6$ & $2.2^{\mathrm{a}} \pm 2.1$ \\
\hline & 17 & $4.0^{\mathrm{b}} \pm 2.6$ & $2.6^{\mathrm{a}} \pm 2.0$ & $2.0^{\mathrm{a}} \pm 1.7$ \\
\hline & 21 & $5.4^{\mathrm{c}} \pm 2.4$ & $3.3^{\mathrm{b}} \pm 2.6$ & $1.8^{\mathrm{a}} \pm 1.4$ \\
\hline & 24 & $5.5^{c} \pm 2.7$ & $3.7^{b} \pm 2.7$ & $1.8^{\mathrm{a}} \pm 1.8$ \\
\hline
\end{tabular}

Mean values with different letter in a row differ significantly from each other $(p<0.05)$ The eat-ripe samples was prepared by ripening green, physiologically mature pears for 7 days at $20^{\circ} \mathrm{C}$. 


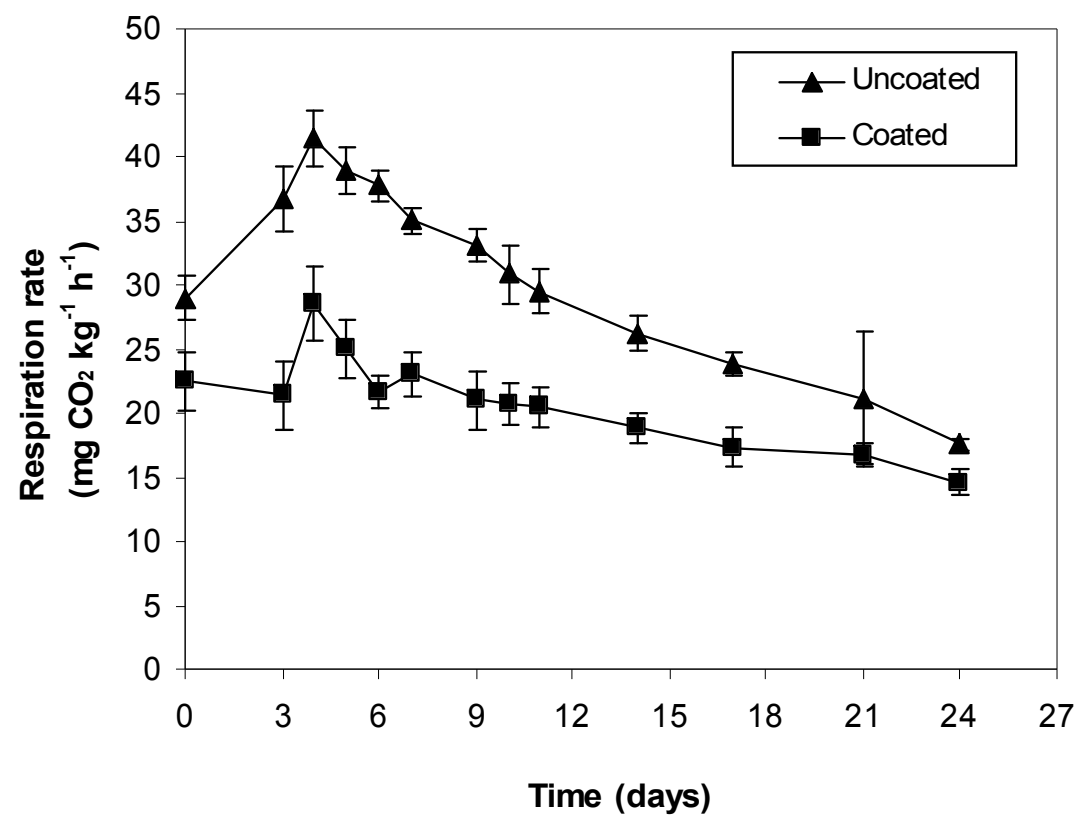

Figure 1. Effect of a $2 \%(\mathrm{w} / \mathrm{w})$ kafirin coating on the respiration rate of 'Packham's Triumph' pears ripened for $24 \mathrm{~d}$ at $20^{\circ} \mathrm{C}(35-45 \% \mathrm{RH})$ 


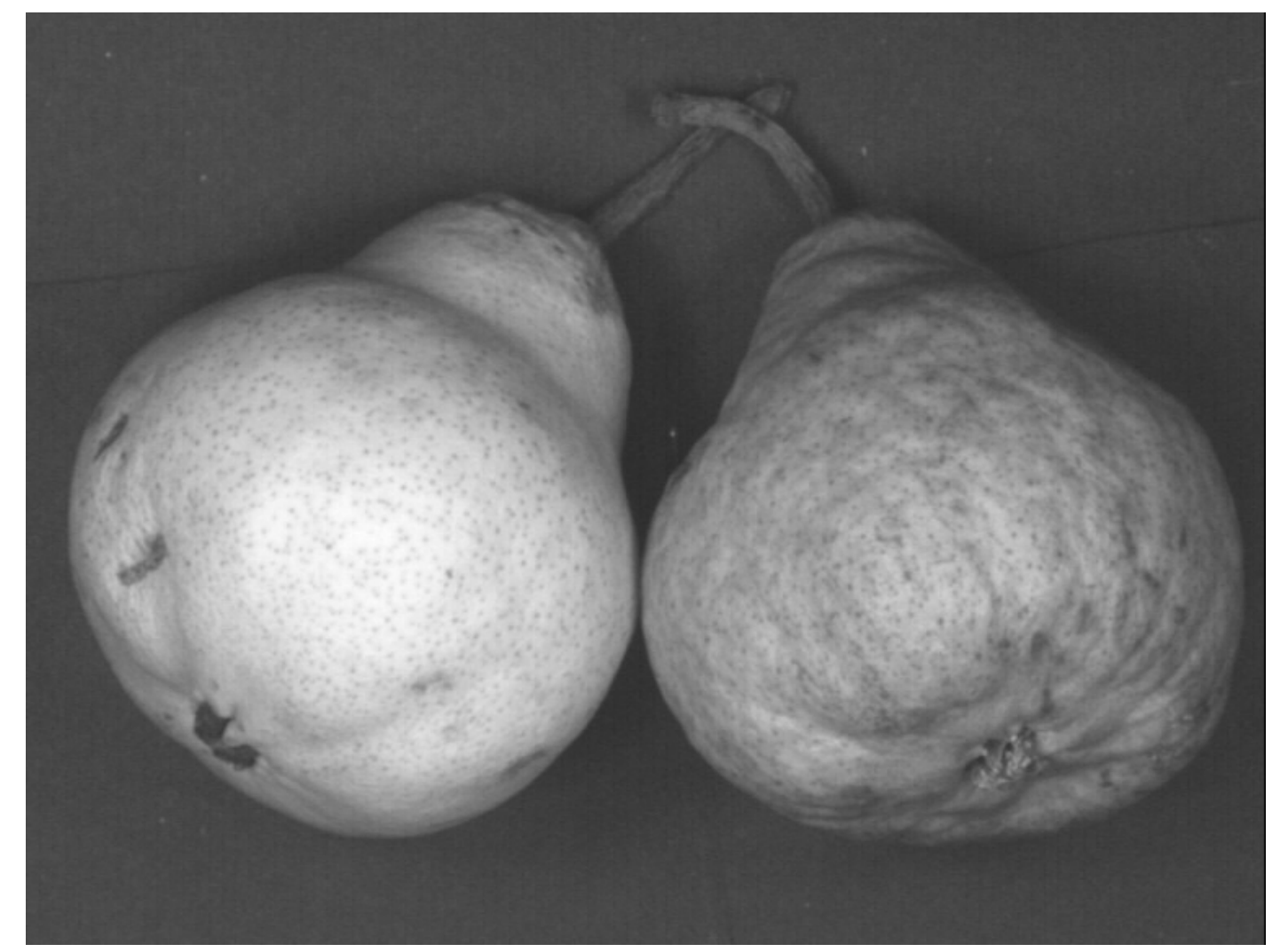

Figure 2. Shrivelling observed on the surface of a $2 \%(\mathrm{w} / \mathrm{w})$ kafirin coated 'Packham's Triumph' pear (right) compared to the skin surface of an uncoated pear (left) after $22 \mathrm{~d}$ of ripening at $20^{\circ} \mathrm{C}(35-45 \% \mathrm{RH})$ 
(a)
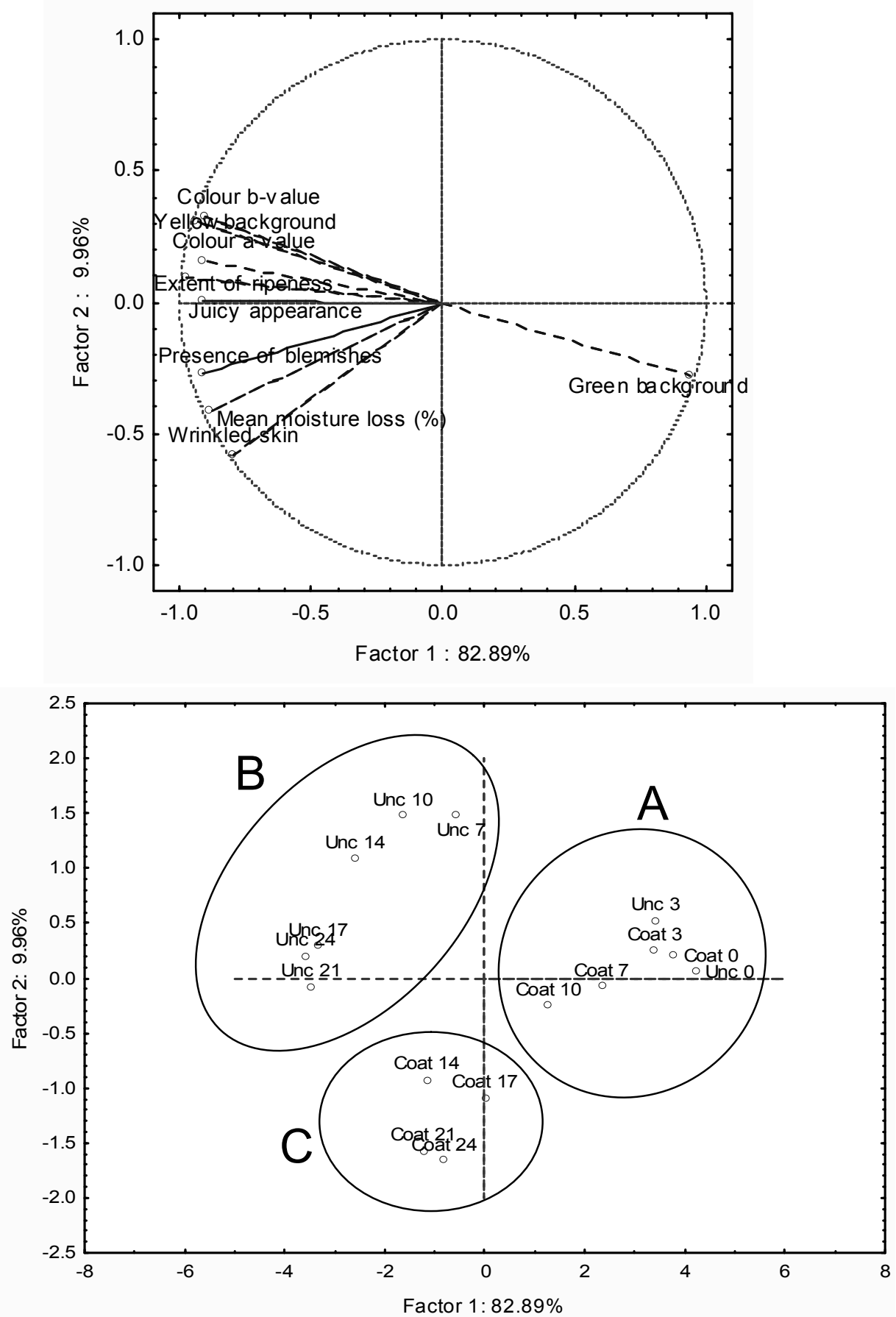

Figure 3. Principal component analysis (PCA) loadings for (a) appearance descriptors and (b) all coated and uncoated pears analysed at and between the start (day zero) and end (day 24) of the shelf-life study. Coat 0-24: coated pears on days 0 to 24 , Unc $0-24$ : uncoated pears on days 0 to 24 . 